NBER WORKING PAPERS SERIES

"LIQUIDATION" CYCLES: OLD-FASHIONED REAL BUSINESS CYCLE THEORY AND THE GREAT DEPRESSION

J. Bradford De Long

Working Paper No. 3546

\author{
NATIONAL BUREAU OF ECONOMIC RESEARCH \\ 1050 Massachusetts Avenue \\ Cambridge, MA 02138 \\ December 1990
}

I wish to thank John Leahy, Murray Milgate, Robert Waldmann, and especially Barry Eichengreen and Randy Kroszner for helpful discussions, and Hoang Quan vu for enthusiastic research assistance. This paper is part of NBER's research program in Financial Markets and Monetary Economics. Any opinions expressed are those of the author and not those of the National Bureau of
Economic Research. 
NBER Working Paper $\$ 3546$

December 1990

\section{"LIQUIDATION" CYCLES: \\ OLD-FASHIONED REAL BUSINESS CYCLE THEORY \\ AND THE GREAT DEPRESSION}

\section{AB8TRACT}

During the 1929-33 slide into the Great Depression, the Federal Reserve took almost no steps to keep the money supply or the price level stable. Instead, the Federal Reserve acted -disastrously -- as if the gathering Great Depression could not be avoided, and was best endured. Such a "liquidationist" theory of depressions was in fact common before the Keynesian Revolution, and was held and advanced by economists like Hayek and Schumpeter. This paper tries to reconstruct the logic of the "liquidationist" view. It argues that the perspective was carefully thought out (although not adequate to the Depression), may hold some truth in other times and places, and could be the core of a more productive research program than currently popular "real" business cycle theories. 


\title{
"Liquidation" Cycles: Old-Fashioned Real Business Cycle Theory and the Great Depression*
}

\author{
J. Bradford De Long \\ Harvard University and NBER
}

first draft March 1989;

this draft October 1990

\begin{abstract}
During the 1929-33 slide into the Great Depression, the Federal Reserve took almost no steps to keep the money supply or the price level stable. Instead, the Federal Reserve acted-disastrously-as if the gathering Great Depression could not be avoided, and was best endured. Such a "liquidationist" theory of depressions was in fact common before the Keynesian Revolution, and was beld and advanced by economists like Hayek and Schumpeter. This paper tries to reconstruct the logic of the "liquidationist" view. It argues that the perspective was carefully thought out (although not adequate to the Depression), may hold some truth in other times and places, and could be the core of a more productive research program than currently popular "real" business cycle theories.
\end{abstract}

\section{Introduction}

The inaction of the United States government during the 1929-33 slide into the Great Depression is, from any of today's various economic perpectives, extraordinarily puzzling. All of today's points of view on how macroeconomic policy should be conducted hold that the govemment should strive to keep some broad nominal aggregate-for new classicals and monetarists, some measure of the nominal money supply; for Keynesians, nominal aggregate demand itself-on a stable growth path. If necessary, the central bank should pour reserves and liquidity into the banking system as fast as possible (and the budgetary authorities should cut taxes and accelerate spending) in order to keep the nominal money stock and total nominal demand from collapsing during incipient depressions.

The Federal Reserve, however, did not push reserves into the banking system during the

\footnotetext{
"I wish to thank John Leahy, Murray Milgate, Robert Waldmann, and especially Barry Eichengreen and Randy Krosznet for helpful discussions, and Hoang Quan Vu for enthusiastic research assistance.
} 
1929-33 decline, even though the nominal money stock fell by a third. Its open market operations were sporadic and were not always on the side of expansion (Temin, 1974). Factions in the Federal Reserve argueing for less deflationary policies were overruled by those who thought that the economy needed to go through a period of "liquidation" in order to lay the groundwork for renewed expansion. "Liquidationists" pointed to the short (albeit sharp) 1921 recession, argued that it had laid the groundwork for the prosperity of the 1920's, and pushed for similar deflationary policies which they hoped would assist the release of capital and labor from socially unproductive activities and lay the groundwork for a similar boom in the 1930's (Eichengreen, 1991).

These policies tumed out to be disastrous in 1929-33. But the current of mind that supported them was not held by makers of policy alone. Such a "liquidationist" theory of the function of depressions was a common position for economists to take before the Keynesian Revolution. It was held and advanced by economists as eminent as Hayek, Robbins, and Schumpeter. In eschewing non-deflationary measures, policy makers in the federal govemment were merely listening to what they had been told by "academic scribblers." They truly were "slaves to some [not yet] defunct economist[s]" (Keynes, 1936).

After the Great Depression, the intellectual victory of the Keynesians was complete. It reduced even the intellectual foundations of pre-Keynesian business cycle theory to rubble. It is not possible, reading either Paul Samuelson (1988) or Milton Friedman (1974), to gain a picture of what pre-Keynesian business cycle theory was. Milton Friedman speaks of an atrophied and rigid caricature of the quantity theory" that could not guide policy. Paul Samuelson speaks of a belief in Say's law which allowed no theoretical room for Depressions.

This paper reconstructs the logic and presents a simple model in the tradition of the "liquidationist" view-in which depressions are unpleasant but unavoidable episodes in the growth of a dynamic economy under uncertainty. In this model attempts to use policies to keep investment, employment, and capacity utilization high in a depression are worse than useless. They are positively destructive. They magnify trouble for the future.

The task of this paper is worth carrying out for three reasons, stated in order of decreasing 
importance. First, it is always worthwhile to do the history of economic thought right. Previous generations of economists were as smart and keen sighted as the present generation. To understand what they believed sheds light both on the actual workings of economies and on economists' present beliefs. Second, the existence of "liquidationism" played a key part in motivating public policy decisions not to fight the gathering Great Depression. The story of economic policy and the economy during the Great Depression cannot be told as it really happened without a coherent picture of the "liquidationist" perspective that so many had adopted.

Third, business cycles have many possible causes and are shaped by different forces in different eras; a "liquidationist" perspective may shed light on business cycles at certain times in certain places-even if it is not helpful for understanding the Great Depression. Modem economics appears to feel a need to have in its box of tools a set of business cycle models in which macroeconomic fluctuations are unavoidable and in some sense "optimal" consequences of the economy's solving a dynamic maximization problem under uncertainty. As it has evolved to date, the modern "real business cycle" research program has relied on downward shifts in the production function to generate reduced investment and output. Friedrich Hayek and Joseph Schumpeter believed in a real business cycle theory, but their framework did not require the embarrassingly ad hoc crutch of large-scale technological regression to account for depressions. Surely a research program that pursued and extended this line of analysis would be more fruitful and lead to more progress than the currently active research program.

\section{The Great Depression and the "Liquidationist" Perspectlve}

From late summer 1929 up to the inauguration of Roosevelt, macroeconomic indicators signalled a grave and immediate need for expansion. The stock market declined in nominal terms at a rate of 35 percent per year, and at 25 percent per year in real terms. The price level and the nominal money stock fell at 8 percent per year. While a flight to quality pushed interest rates on government securities and on short-run paper issued by credit-worthy firms down, the nominal interest rates at which corporations could borrow for the long term rose (Temin, 1974). 


\section{Flgure 1}

\section{Macroeconomic Variables in the Great Depression}

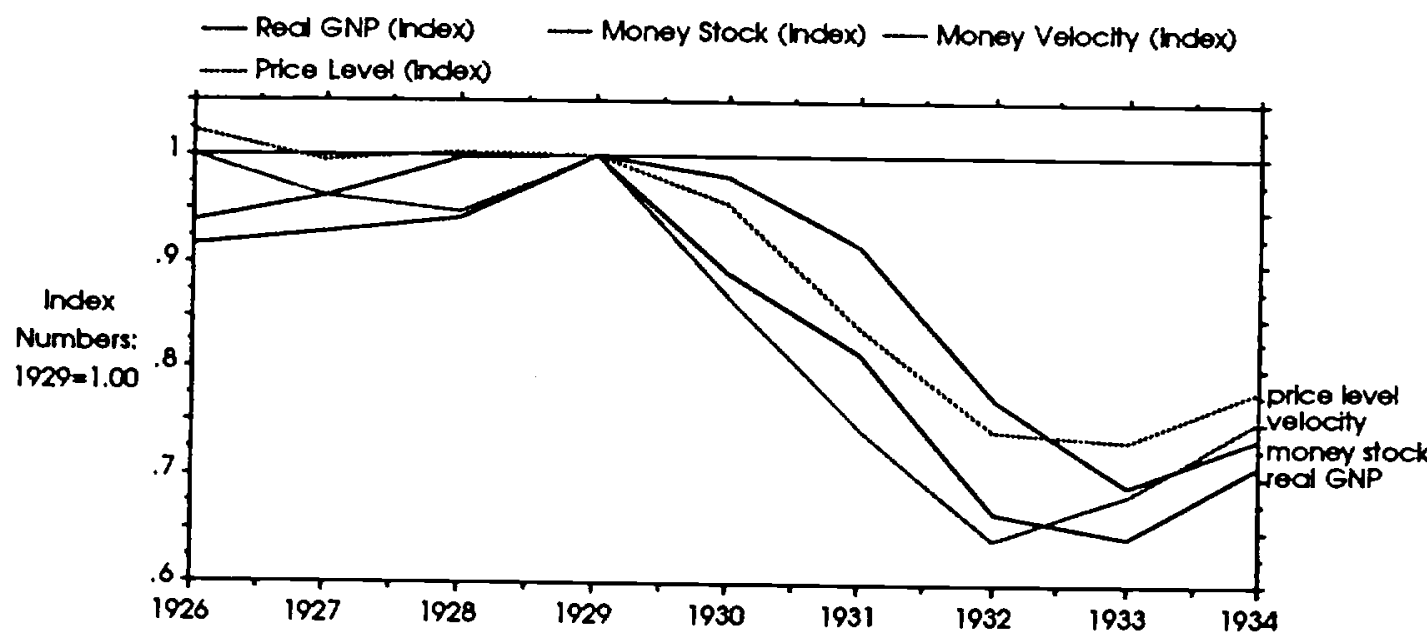

\section{Economic Policy Under Hoover}

Throughout this decline-which carried real GNP per worker down to a level 40 percent below that which it had attained in 1929, and which saw the unemployment rise to take in more than a quarter of the labor force-the govemment did not try to prop up aggregate demand. The only expansionary fiscal policy action undertaken was the Veterans' Bonus, passed over President Hoover's veto (Chandler, 1970). That aside, the full-employment budget surplus did not fall over 1929-33 (Brown, 1956).

The Federal Reserve did not use open market operations to keep the nominal money supply from falling. Instead the only significant systematic use of open market operations was in the other direction: to raise interest rates and discourage gold outflows after the United Kingdom abandoned the gold standard in the fall of 1931 (Temin, 1974). The Federal Reserve's inaction did not come about because they did not understand the tools of monetary policy. They had used the tools of monetary policy often in the 1920's, and again in the fall of 1931 (Friedman and Schwartz, 1963). The Federal Reserve's inaction did not come about because of the necessity to defend the gold standard. The United States in 1931 held nearly half the world's gold reserves, 
and was far from the point where a looser monetary policy might trigger a successful speculative attack on the U.S.'s adherence to the gold standard (Eichengreen, 1991).

The Federal Reserve thus knew what it was doing: it was letting the private sector handle the Depression in its own fashion. It saw the private sector's task as the "liquidation" of the American economy. And it feared that expansionary monetary policy would impede the necessary private-sector process of readjustment. Contemplating the wreck of his country's economy and his own political career in retrospect, Herbert Hoover wrote bitterly about those in his administration who had advised inaction during the downslide into the Great Depression:

\begin{abstract}
The 'leave-it-alone liquidationists' headed by Secretary of the Treasury Mellon...felt that government must keep its hands off and let the slump liquidate itself. Mr. Mellon had only one formula: 'Liquidate labor, liquidate stocks, liquidate the farmers, liquidate real estate'.... He held that even panic was not altogether a bad thing. He said: 'It will purge the rottenness out of the system. High costs of living and high living will come down. People will work harder, live a more moral life. Values will be adjusted, and enterprising people will pick up the wrecks from less competent people' (Hoover, 1952, vol. 3, p. 30).1
\end{abstract}

\title{
Economic Theory During the Hoover Administration
}

The Hoover administration's and the Federal Reserve's unwillingness to use fiscal of monetary policy to prop up aggregate demand during the slide into the Great Depression was approved by the most eminent economists of the day. From Harvard, Seymour Harris argued that just because the banking system was near collapse was no reason for the Federal Reserve to buy bonds for cash: "Open market operations are not the most effective method of dealing with... bank failures, any more than the proper way of filling numerous small holes on the surface of the earth is to flood the earth with water" (Harris, 1934; p. 104). Joseph Schumpeter argued that there was a "presumption against remedial measures which work through money and credit... policies of this class are particularly apt to...produce additional trouble for the future"

\footnotetext{
${ }^{1}$ Quoted in Wiseley (1977), p. 118, and then requoted in Kindlebetger (1978), pp. 139-40.
} 
(Schumpeter, 1934; p. 20).

Schumpeter (1934) gives the clearest literary exposition of the "liquidationist" line of argument believed by Mellon, other makers of policy, and economists like Hayek (1931, 1935), ${ }^{2}$ Harris (1934), and Robbins (1934). Schumpeter begins from the observation that the course of economic development is never smooth. Investments and enterprises are gambles on the future. Sometimes these gambles will fail, and the actual future that comes to pass will be one in which certain investments should not have been made and certain enterprises should not have been undertaken. The best that can be done in such circumstances is to shut down those production processes that turned out to have been based on assumptions about future demands that did not come to pass, or that have been made obsolete by technological development. The liquidation of such investments and businesses releases factors of production from unprofitable uses; they can then be redeployed in other sectors of the technologically dynamic economy; but without the initial liquidation the redeployment cannot take place.

It follows, says Schumpeter, that depressions are this process of liquidation and preparation for the redeployment of resources. From Schumpeter's perspective, “depressions are not simply evils, which we might attempt to suppress, but...forms of something which has to be done, namely, adjustment to...change." This socially productive function of depressions creates "the chief difficulty" faced by economic policy makers. For "most of what would be effective in remedying a depression would be equally effective in preventing this adjustment" (Schumpeter, 1934; p. 16). The process of dynamic economic growth requires that underutilized factors of production register their availability on factor markets. Policies that stimulate aggregate demand in recessions keep factors of production engaged in activities that do not produce value in excess of their social cost, and so keep factor markets from registering the potential availability of productive resources for redeployment.

\footnotetext{
2"Austrian" economists were not the only source, even though they were one source, of liquidationist doctrines. "Austrian" attempts to develop formal business cycle theories, however, did not mesh well with their approach to capital theory and the determination of the rate of interest. The businessmen's point of view as laid out by Mellon, and the theoretical frameworks sketched out by Robbins and Schumpeter are flawlessly transparent compared to the opaque writings of Hayek.
} 
Schumpeter goes so far as to argue that monetary policy does not allow policy makers to choose between depression and no depression, but between depression now and a worse depression later. He argues that "inflation...pushed far enough [would] undoubtedly tum depression into the sham prosperity so familiar from European postwar experience but...would, in the end, lead to a collapse worse than the one it was called in to remedy" (Schumpeter, 1934; p. 16). Hence Schumpeter's “...analysis leads us to believe that recovery is sound only if it does come of itself. For any revival which is merely due to artificial stimulus leaves part of the work of depressions undone and adds, to an undigested remnant of maladjustment, new maladjustment of its own which has to be liquidated in tum, thus threatening business with another [worse] crisis ahead" (Schumpeter, 1934; p. 20).

Since the basic maladjustment is past investments and lines of business that have turned out to be socially unproductive and in need of liquidation, the "trouble is fundamentally not with money and credit." And so stimulative monetary "policies...are particulary apt to keep up, and add to, maladjustment, and to produce additional trouble for the future" (Schumpeter, 1934; p. 20). Moreover, words like "stimulative" carry a special meaning in this context: if private sector actions would lead to a fall in, say, the nominal money stock, then a public sector attempt to counteract the consequences of such private-sector actions by injecting sufficient reserves to hold the nominal money stock constant would be "stimulative."

Lionel Robbins (1934) even goes so far as to attribute the extraordinary depth and length of the Great Depression to expansionary monetary policy, writing that: "The moment the boom broke...the Central Banks of the world... set to work to create a condition of easy money....The process of liquidation was arrested." And this was a mistake, for:

In...a boom many bad business commitments are undertaken....[Goods] are produced... which it is impossible to sell at a profit. Loans are made which it is impossible to recover....[W] ...commitments are revealed....Nobody wishes... bankruptcies. Nobody likes liquidation as such.... [But] when the extent of mal-investment and over-indebtedness has passed a certain limit, measures which postpone liquidation only make matters worse (Robbins, 1934, p. 62). 
Robbins' diagnosis was that the world economy in the 1930's needed more, not less deflation: "In the present depression we eschew the sharp purge. We prefer the lingering disease." And Hayek's (1931) rejection of expansionary policies is the same: the belief "that a general crisis can be averted by extension of credit" is a "popular fallacy." Moreover, "the great expectations attached to...public works in times of depression [are]...fallacious," for public works also "bring about all those evil effects which...arise when [the] money [supply] is increased."

If markets functioned smoothly the redistributions of labor and machines from socially unproductive to socially productive lines of enterprise would require neither unemployment nor idle capacity. Frictions in markets-labor unions, relocation costs, imperfect information, and so forth-mean that this process of reallocation entails unemployment, slack capacity, and temporarily reduced production. Before entrepreneurs in expanding lines of business can become aware of the availability of additional factors of production, such factors of production must be released from their past uses and spend some time in "inventory." Thus Robbins and Schumpeter argued that the appropriate policy response was not to try to pump up aggregate demand and so stop the process of liquidation and reallocation: that process would have to be carried through eventually; postponing it simply magnified the social costs. Instead, the appropriate policy response was to reduce the frictions.

This doctrine-that in the long nun the Great Depression would turn out to have been "good medicine" for the economy, and that proponents of stimulative policies were shortsighted enemies of the public welfare-drew anguished cries of dissent from others. The British economist Ralph Hawtrey scorned those who, like Robbins, wrote at the nadir of the Great Depression that the greatest danger the economy faced was inflation. It was, Hawtrey said, the equivalent of "Crying, 'Fire! Fire!' in Noah's flood."3 Milton Friedman (1974) recalled that at Knight, Simons, and Viner's Chicago such dangerous nonsense was not taught, but he understood why at Harvard-where such nonsense was taught-bright young economists might

\footnotetext{
${ }^{3}$ I owe this quotation to Peter Temin.
} 
rebel, reject their teachers' macroeconomics, and become Keynesians. ${ }^{4}$

John Maynard Keynes himself (1931) tried to discredit the "liquidationist view" with the rhetoric of ridicule. He called it an "imbecility" to argue that the "wonderful outburst of productive energy" during the boom of 1924-29 had made the Great Depression inevitable. And he spoke of Hayek, Robbins, Schumpeter, and their fellow travelers as:

...austere and puritanical souls [who] regard [the Great Depression]...as an inevitable and a desirable nemesis on so much "overexpansion" as they call it....It would, they feel, be a victory for the mammon of unrighteousness if so much prosperity was not subsequently balanced by universal bankruptcy. We need, they say, what they politely call a 'prolonged liquidation' to put us right. The liquidation, they tell us, is not yet complete. But in time it will be. And when sufficient time has elapsed for the completion of the liquidation, all will be well with us again...

(Keynes, 1972; vol. XIII, pt. 1, p. 349)

In spite of opposition, the "liquidationist" view carried the day over virtually the entire world during 1929-33, and over much of the world during 1933-39. Even governments that had unrestricted international freedom of action-like France and the United States with their massive gold reserves, and like Britain after its departure from the gold standard-tended not to pursue expansionary monetary and fiscal policies on the grounds that such would reduce investor "confidence" and hinder the process of liquidation, reallocation, and the resumption of private investment (see Temin, 1990; Eichengreen, 1991; Hall, ed., 1989).

\section{The Eclipse of the "Liquidationist" View}

After the Great Depression and World War II the victory of the Keynesians was complete. Nothing was left of the doctrines of their "liquidationist" opponents-it was not easy to learn what their doctrines had been. ${ }^{5}$ Keynesian and monetarist accounts reduced even the intellectual

\footnotetext{
${ }^{4}$ Friedman's report on the state of Chicago thought during the early stages of the Depression is supported by Davis (1971); it is challenged by Patinkin (1978) and by Johnson (1969).

${ }^{5}$ Salant (1989) is one of the few chroniclers of the Keynesian revolution who refers to "liquidationism." calling it the "'crime and punishment' theory of business cycles.
} 
foundations of pre-Keynesian business cycle theory to rubble. Post-World War II

macroeconomics courses and texts taught how one got from a model of Walrasian equilibrium to one with Keynesian (or monetarist) business cycles (Patinkin, 1982). They did not teach how modem theories were better, or even what the theories of their predecessors had been. 6

Figure 2

United States Economlc Growth, 1890-1988

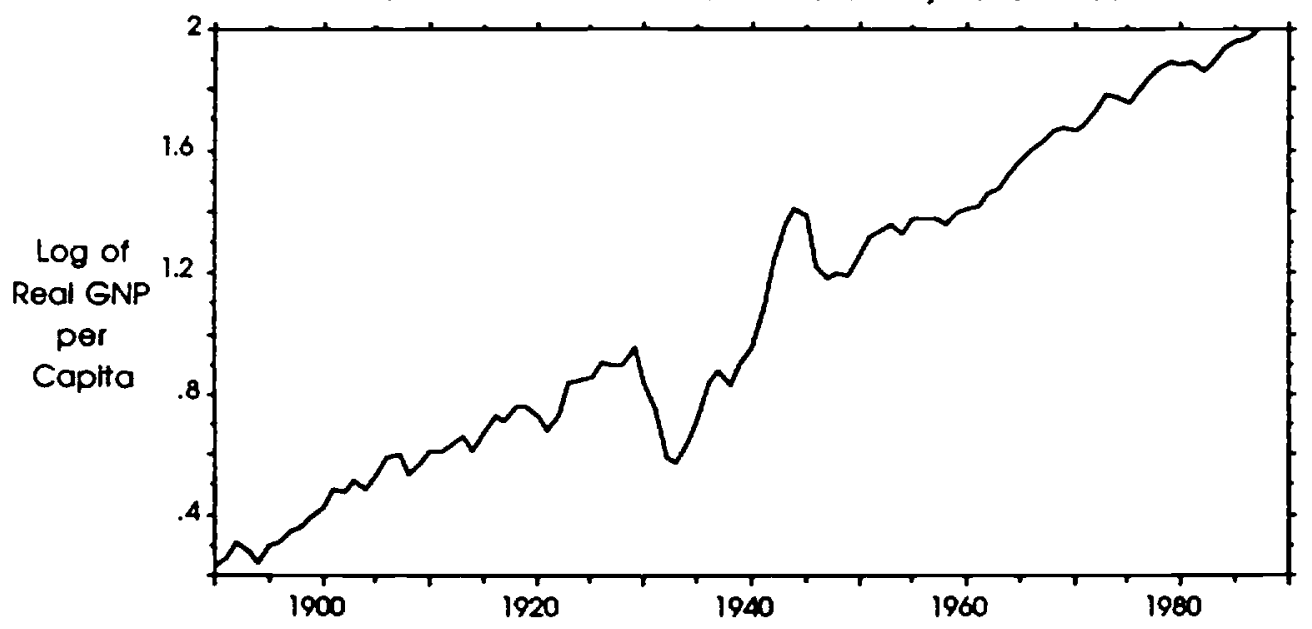

As a result, it is not possible reading either Paul Samuelson or Milton Friedman today to gain a picture of what pre-Keynesian business cycles were. In asides Friedman (1974) speaks of an "atrophied and rigid...quantity theory" that could not guide policy, and Samuelson (1988) speaks of a belief in Say's law, which gave no theoretical room for Depressions. The impression left is that before Keynes economists had a theory of full employment equilibrium but no theory

${ }^{6}$ Dim echos of some "liquidationist" concerns can be heard in some of the internal debate within monetarism over which monetary aggregate to stabilize. For the early Friedman (1974), this was an empirical question: which monetary aggregale is the best leading indicator of total nominal demand? For others like Brunner and Meltzer (1974), or like the later Friedman (1984), this was a theoretical question: stabilizing which monetary aggregate corresponds to the government's not distorting privare-sector incentives? Pre-Keynesian debates over just what a "neutral" monetary policy was could become bighly scholastic. Hayek (1931), for example, sees a world of difference between a policy that stabilizes the nominal stock of outside money and one that maintains a stable price level. The second, he believes, distorts private-sector incentives and inevitably paves the way for crises and depressions-he saw one of his major intellectual tasks as the overthrow of "the dogma of the stable price level" (Hayek, 1931). 
of fluctuations, and so could not provide reasoned support for policies to counteract depressions. In fact, things were worse: Hayek, Robbins, and Schumpeter had a theory of the business cycle, but it ruled out as destructive just those policies that monetarists and Keynesians wished to see.

It was unfortunate for the economy that liquidationists were influential, and tried to apply their theory to the Great Depression where it does not fit. Figure 2 plots the course of real GNP per capita in the United States since 1890. While other recessions and depressions to be found in the figure might possibly be interpretable as the liquidation of mistaken investments that inevitably takes place in a dynamic economy under uncertainty, the Great Depression is too large for such an interpretation to pass a minimal plausibility test: during the Great Depression real national product per capita fell back to its level of a quarter century before, and the U.S.'s real capita stock declined to its level of the early 1920's.

It was unfortunate for the liquidationists as well that they tried to apply their theory to the Great Depression. Their catastrophic failure left them intellectually bankrupt. Even Lucas who, seeking intellectual ancestors, has written approvingly of pre-Keynesian theory as based on the “...idea of mistaken...decisions triggered by spurious ...signals" and on understanding these mistaken decisions “....as intelligent responses to movements in nominal 'signals' of movements in the underlying 'real' events we care about and want to react to," has hastened to dismiss the substantive views of the liquidationist school (Lucas, 1981; pp. 9, 237).

\section{Modelling Llquidation Cycles}

This section of this paper develops a simple theoretical model of a "liquidationist" business cycle, in which large fluctuations in investment are driven by small fluctuations in expectations of the future. An economy solving a dynamic social maximization problem at times finds itself in a situation where the "liquidation" of capital, enterprises, and sunk investments is optimal. The main objective of this section is to "do the history of economic thought right" by translating the business cycle theories of Hayek and Schumpeter into the same theoretical language in which other business cycle theories are expressed. 
In the process, a certain amount of value is added. For example, Hayek's (1935) Prices and Production and his (1931) "'Paradox' of Saving" are monsters with tangled and roundabout arguments about business cycles that do not mesh with the "Austrian" theoretical apparatus Hayek uses (which had been designed to analyze the equilibrium real rate of interest, and not business cycles). And Schumpeter was no model builder. Gaps must be filled in to raise their story to the level of consistency and formalization that modem economists expect. Translation inevitably involves shifts in meaning, and translation into the language of modem economic theory especially so. Modem economic theory is a language that enforces a high degree of consistency and explicit formalization on arguments made in it-a higher degree than either Hayek or Schumpeter attained in their own presentations of their position. ${ }^{7}$

\section{Building Blocks}

The model constructed here is by no means complete. It is a model of substantial business cycle-like investment fluctuations that are, given the shadow costs of resources, due to investors' optimal attempts to "pierce the veil of time and ignorance" (in Keynes' words). They do not account for why, once released from the investment sector, productive resources remain idle and in "inventory" for a time- that is presumably due to various market "frictions." 8 This section thus presents only the "accelerator" portion of a "liquidationist" business cycle.

Assume that the economy is populated by $n$ identical firms, each of which faces costs of investing at rate $i_{1}$ given by:

$$
i_{t}+\frac{n}{2 \delta} \frac{\left(i_{t}\right)^{2}}{K_{t}}
$$

where $K_{t}$ is the economy-wide total capital stock, $i_{\mathfrak{l}}$ denotes the rate of investment by each

\footnotetext{
7The model of this section also suppresses one current in "liquidationist" thought that saw a share of the "overbuilding" in a boom as a result of irrational speculative excess that led to investments that were poor bets ex ante. According to this current, there are good decision makers and bad decision makers; all kinds prosper in a boom; only in a recession does the Darwinian market select against bad decision makers; so, without recessions, the quality of economic leadership would over time become increasingly degraded.

${ }^{8}$ Pre-Keynesian theorists regarded these frictions as important for assessing the distributional costs of business cycles, but remote from the central engine of the cycle itself.
} 
individual firm, and $\delta$ is an unchanging parameter. Aggregate up to obtain the total rate of investment $I_{t}$ for the economy as a whole:

(2) $\quad I_{t}=n\left(i_{t}\right)$

Define $q^{s} t$ as the expected present value of the future quasi-rents received from year $t$ forward by a unit of capital put in place in year $s$. For simplicity, write $q_{t}$ for $q_{t} t_{-}$the expected present value of the returns from an extra unit of capital put in place today. Assume a constant real required rate of retum $r$. Setting the cost of a marginal unit of capital equal to its expected future quasi-rents, iinvestment and (in the absence of depreciation) the proportional growth of the capital stock will then satisfy:

$$
\delta\left(q_{t}-1\right)=\frac{I_{t}}{K_{1}}=\frac{\dot{K}_{t}}{K_{t}}
$$

Now tum to the quasi-rents received by a unit of capital. We assume that, at all times $t>s$, a unit of capital installed at time s yields a flow quasi-rent, denoted $d_{t}$ :

$$
d_{t}^{*}=\frac{\alpha_{t}}{k}
$$

where $\alpha_{t}$ is an index of total productivity of the economy at time $t$, and $K_{s}$ is the total amount of capital installed at all earlier times and in place at time s. Old capital is thus more valuable than new capital-think of an economy with an unlimited number of investment projects of decreasing value, the returns to all of which grow as the technological level of productivity grows. $\alpha_{4}$ grows at a proportional rate:

$$
\frac{\dot{\alpha}_{t}}{\alpha_{t}}=g
$$

with:

$$
\dot{g}_{1}=\varepsilon_{1}-\frac{\sigma_{\varepsilon}^{2}}{r-g_{1}}
$$


where $\varepsilon_{t}$ is a random variable and $\int_{\varepsilon_{t}} d t$ is a Brownian motion. The proportional growth rate $g_{t}$ of $\alpha_{q}$ thus locally follows a continuous time random walk, but its drift varies over time.

Two nuisance adjustments to the model are necessary in order to allow for the production of simple closed-form solutions. The first is the nuisance term $\sigma_{\varepsilon}{ }^{2} /\left(r-g_{t}\right)$ in equation (6). ${ }^{9}$ The second is a small nuisance adjustment to the specification: whenever capital is liquidated and disinvestment takes place, the profits from the disinvestment are received by middlemen: owners of the capital receive only the expected present value of future quasi-rents, and not the net liquidation value after de-installation costs. ${ }^{10}$

To derive the shadow value of capital, consider first as a heuristic device the discrete-time version of our continuous time model and then let the duration of each discrete period approach zero. Break time into periods of length $\tau$, and substizute discrete random variables $\sqrt{ } \tau\left(\varepsilon_{t}\right)$ for the continuous time stochastic terms.

Investments in capital must eam the required retum of $\mathrm{r}$ in expectation:

$$
(1+\tau) q_{t}^{2}=\tau \frac{\alpha_{t}}{K_{s}}+E q_{q+\tau}
$$

Defining a new function $\theta$ :

$$
q_{1}^{\prime}=\frac{\alpha_{1}}{K_{3}} \theta\left(g_{2}\right)
$$

and substituting into (7):

$$
(1+\tau r) \theta(g)=\tau+\left(1+\tau g_{l}\right) E_{t}\left(\theta\left(g-\tau \sigma_{e}^{2} /\left(r-g_{l}\right)+V \tau\left(\varepsilon_{l}\right)\right)\right)
$$

Taking a Taylor expansion:

\footnotetext{
9 The ouisance term is quantitatively insignificant: for the parameter values used in the simulations below, it is typically on the order of $0.008 \%$ per year. It is included only in order to obtain simple closed-form expressions for q.

10 This adjustment allows us to ignore the "option value" generaled by the existence of the option of liquidating sunk capital should its quasi-rent drop low enough. Once again, this adjustment is quantitatively insignificant.
} 


$$
\tau r \theta\left(g_{t}\right)=\tau+\tau g_{t} \theta\left(g_{1}\right)-\left(1+\tau g_{l}\right)\left\{\frac{\tau \sigma_{\varepsilon}^{2} \theta^{\prime}\left(g_{1}\right)}{r-g_{l}}+\frac{\tau \sigma_{\varepsilon}^{2} \theta^{\prime \prime}\left(g_{l}\right)}{2}\right\}+O\left(\tau^{2}\right)
$$

Dividing by $\tau$ and letting $\tau$ approach zero:

$$
\left(\mathrm{r}-\mathrm{g}_{\mathrm{l}}\right) \theta\left(\mathrm{g}_{\mathrm{q}}\right)=1-\frac{\sigma_{\varepsilon}^{2} \theta^{\prime}\left(\mathrm{g}_{\mathrm{q}}\right)}{\mathrm{r}-\mathrm{g}_{\mathrm{q}}}+\frac{\sigma_{\varepsilon}^{2} \theta^{\prime \prime}\left(\mathrm{g}_{\mathrm{q}}\right)}{2}
$$

(11) has a fundamental solution:

$$
\theta\left(g_{t}\right)=\frac{1}{r-g_{t}}
$$

We neglect the non-fundamental "bubble solutions." From (12):

$$
q^{s}=\frac{\left[\alpha / K_{s}\right]}{r-g_{t}}
$$

and:

$$
q=q^{t}=\frac{[\alpha / K}{r-g}
$$

follow. Equation (14) gives the current $\mathrm{q}_{t}$, the shadow value of the marginal investment project as a function of the capital/technology ratio $K_{t} / \alpha_{t}$ and the expected future growth rate $g_{t}$.

\section{Dynamic Response to a Single Shock}

Insight into the dynamic behavior of this model can be gained by considering the response of the model to a lone unanticipated shock. Figure 3 presents the deterministic dynamics of the model in response to a unique once-and-for-all shock.

The $q(K)$ schedule represents the current value of $q$-the present value of expected quasirents eamed by the marginal unit of capital-given the required rate of return $r$, the current rate of technology growth $g_{t}$, and the current value of $K / \alpha$, the capital stock relative to the current level of technology. The economy is always on the $q(K)$ locus, at a point determined by the 
current value of the state variable $K / \alpha$ The $(K / \alpha)$ is constant locus, at $q=1+g_{l} / \delta$, consists of those points at which investment takes place just fast enough to keep the capital stock growing at the same rate as the technology parameter $\alpha$

\section{Figure 3}

Investment Equilibrium in $(q, K / \alpha$ Space

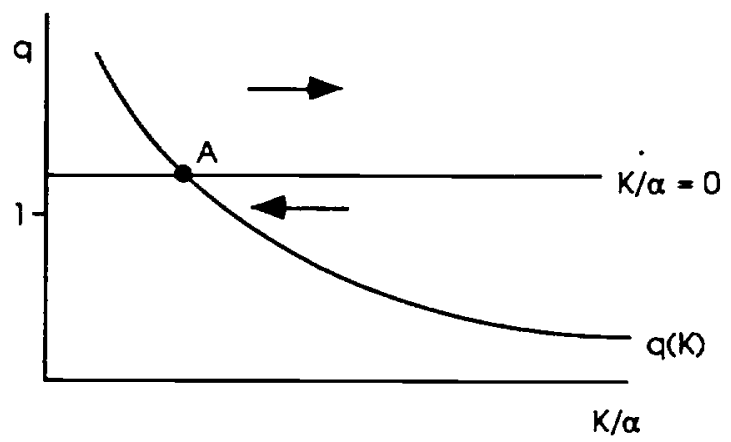

If the economy is to the right of point $A$ on the $q(K)$ locus, the capital stock is not increasing fast enough to keep $K / \alpha$ constant, and the economy drifts to the left along the $q(K)$ curve. If the economy is to the left of point $A, q_{t}$ is high and induces enough investment to make $\mathrm{K} / \alpha$ rise and the economy drifts to the right. In the absence of shocks, the deterministic dynamics of the system lead it to come to rest at point $A$, with $K / \alpha=\left\{\left(r-g_{t}\right)\left(1+g_{t} / \delta\right)\right\}^{-1}$ and $q=1+g_{t} / \delta$

Flgure 4

Response to a Permanent Negatlve Shock to Future Growth

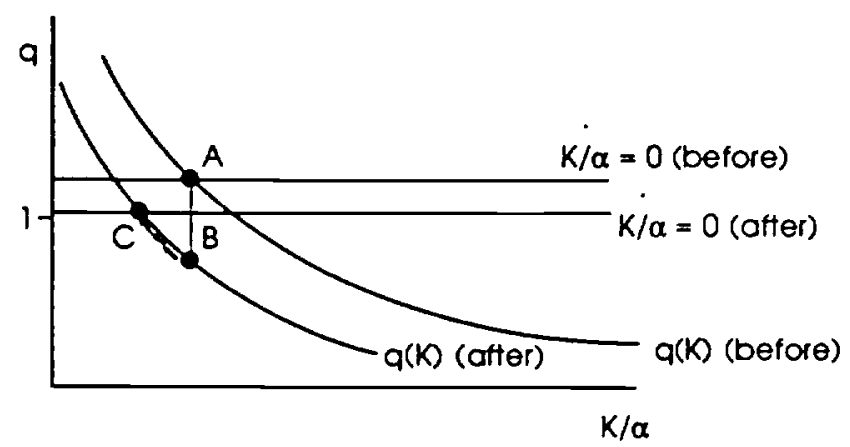


Now consider how this model reacts to a previously-unanticipated permanent negative shock to the rate of technological progress $\mathrm{g}_{t}$, as plotted in figure 4 . The constant $(\mathrm{K} / \alpha)$ locus shifts downward - because of the slower growth in $\alpha$, a lower level of $q$ than before keeps K/ $\alpha$ constant. In addition, the $\mathrm{q}(\mathrm{K})$ locus shifts to the left: since the new denominator of (14) is lage, the same value of $\mathrm{q}$ requires a smaller value of $\mathrm{K} / \alpha$

For suitable parameter values $\left(g_{t}>(r-\delta) / 2\right)$ ), this reduction in the expected future growth rate reduces the deterministic fixed point value of $\mathrm{K} / \alpha$. In response to the shock, the economy jumps to point $B$, and disinvestment begins. The rate of growth of $K / \alpha$ becomes negative: given the new rate of technological change, the most recent units of capital built were: not worth their resource cost. In the absence of additional shocks, $K / \alpha$ falls until the economy reaches equilibrium at a new, lower level of $K / \alpha$, denoted by $C$ in figure 4 . And as long as the value of $q$ at point $B$ is less than one, optimal adjustment requires absolute disinvestment-not just a slowing of the pace of investment.

\section{Comparison with Standard $q$-Theory Dynamics}

The previous subsection has laid out a "liquidationist" account of how bad news about future productivity growth plausibly causes a fall in the demand for investment goods and a fall in the stock of capital as well. Properly augmented by "frictions" that cause factors of production released from the capital goods sector to spend time in "inventory" before they are reemployed in other sectors, it could serve as a model of the business cycle. " The "accelerator" in the subsection above provides a rationale for why reallocation of resources from consumption to investment goods sectors and back again is pervasive. The economy, maximizing a suitable objective function, must determine how much of its resources to devote to capital without knowing what the long run productivity growth rate will tum out to be ex post. The economy

\footnotetext{
${ }^{11}$ One such account of how the reallocation of productive resources actoss sectors could lead to unemployment is given by Lilien (1982).
} 
must guess; inevitably there will be times it discovers that it has overestimated future growth and so built capital "ahead of demand." The subsequent process of adjustment sees disinvestment and "liquidation."

Importantly, note that the fall in investment and the capital goods stock does not in any sense rely on short-term technological regression. The level of technology that can be used in production does not fall. Instead, recognition that the future rate of growth of technology will be slower carries with it a realization that there is an "overhang" of capital, and that old capital should be scrapped and new investment projects postponed until this capital overhang has been absorbed.

It is worthwhile to compare the response of investment to news about the future rate of growth of productivity in this model to the response of investment in a standard model of investment dynamics like that of Blanchard-Fischer (1988). In the Blanchard-Fischer model there is no advantage to having been the "first mover" in the accumulation of capital. All units of capital eam the same quasi-rents and compete on equal footing. As a result, bad news about future productivity growth leads to a slowing-down of investment, but it never leads to a fall in the desired ratio of capital to the productivity parameter $\alpha$ or to the desired scrapping of existing capital.

Figure 5

Response to a Permanent Negative Shock to Future Growth In the Blanchard-Flscher Model

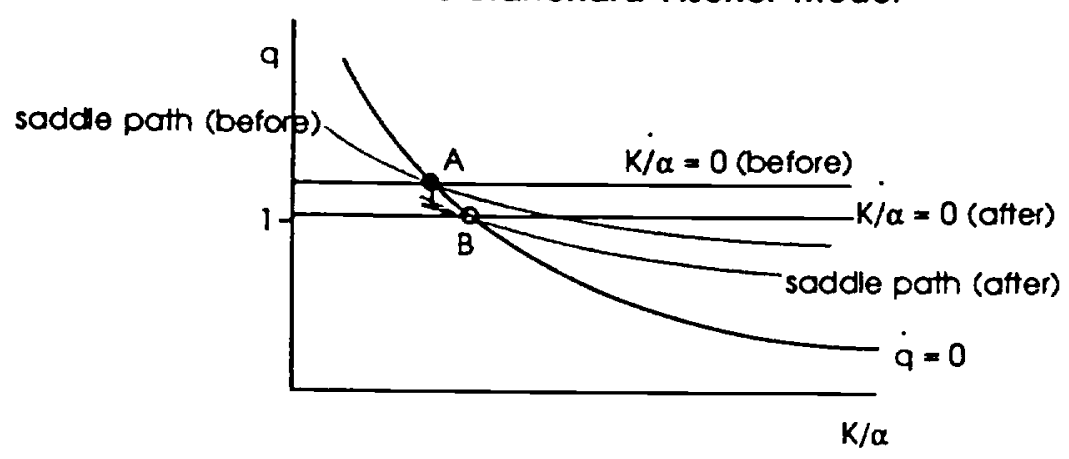


Figure 5 plots the Blanchard-Fischer phase space dynamics of the model with equation (4) replaced by:

$$
\text { (4') } d_{t}=\frac{\alpha_{t}}{K_{t}}
$$

in which all units of capital in place at time $t$ earn the same quasi-rent, given by the quotient of the technology parameter $\alpha_{\mathfrak{l}}$ and the capital stock in place $K_{t}$. News that future productivity growth will be lower shifts the $K / \alpha=$ consiant locus down: a slower rate of investment is now sufficient to keep the economy on its steady-state growth path. The $q=$ constant locus does not shift. Since the long-run saddle point equilibrium in figure 5 is given by the intersection of the $q$ $=$ constant and the $\mathrm{K} / \alpha=$ constant curves, it follows immediately that the desired long-run $\mathrm{K} / \alpha$ ratio rises-it cannot fall-in response to bad news about future productivity growth. In the Blanchard-Fischer model, therefore, a sudden fall not just in the growth rate but in the level of technology is required to generate a fall in the desired capital stock, and absolute disinvestment.

\section{Dynamic Response to a Process of Shocks}

The model has provided a consistent and formalized example of what Schumpeter and others were talking about when they attributed recessions to the realization, in a stochastic environment, that the economy had accumulated either "too much" or "the wrong kind" of capital. In response to a stochastic shock process, the model economy does indeed exhibit "business cycles." At times good news about future growth leads to an investment boom, as entrepreneurs hasten to put in place a large chunk of new capital that is expected to be profitable given the forecast future path of productivity. And at times the economy goes into depressions: news about future growth rates reveals that the capital stock has been overbuilt, and that there will be a substantial period of time during which it will be optimal for there to be no investment or disinvestment.

Figures 6 and 7 plot simulated investment cycles driven by news about future growth rates. Figure 6 presents four simulation runs. For each run it presents four panels, plotting the time 
Flgure 6

SImulated Time Paths of Investment, Growth, Caplial, and Productivity
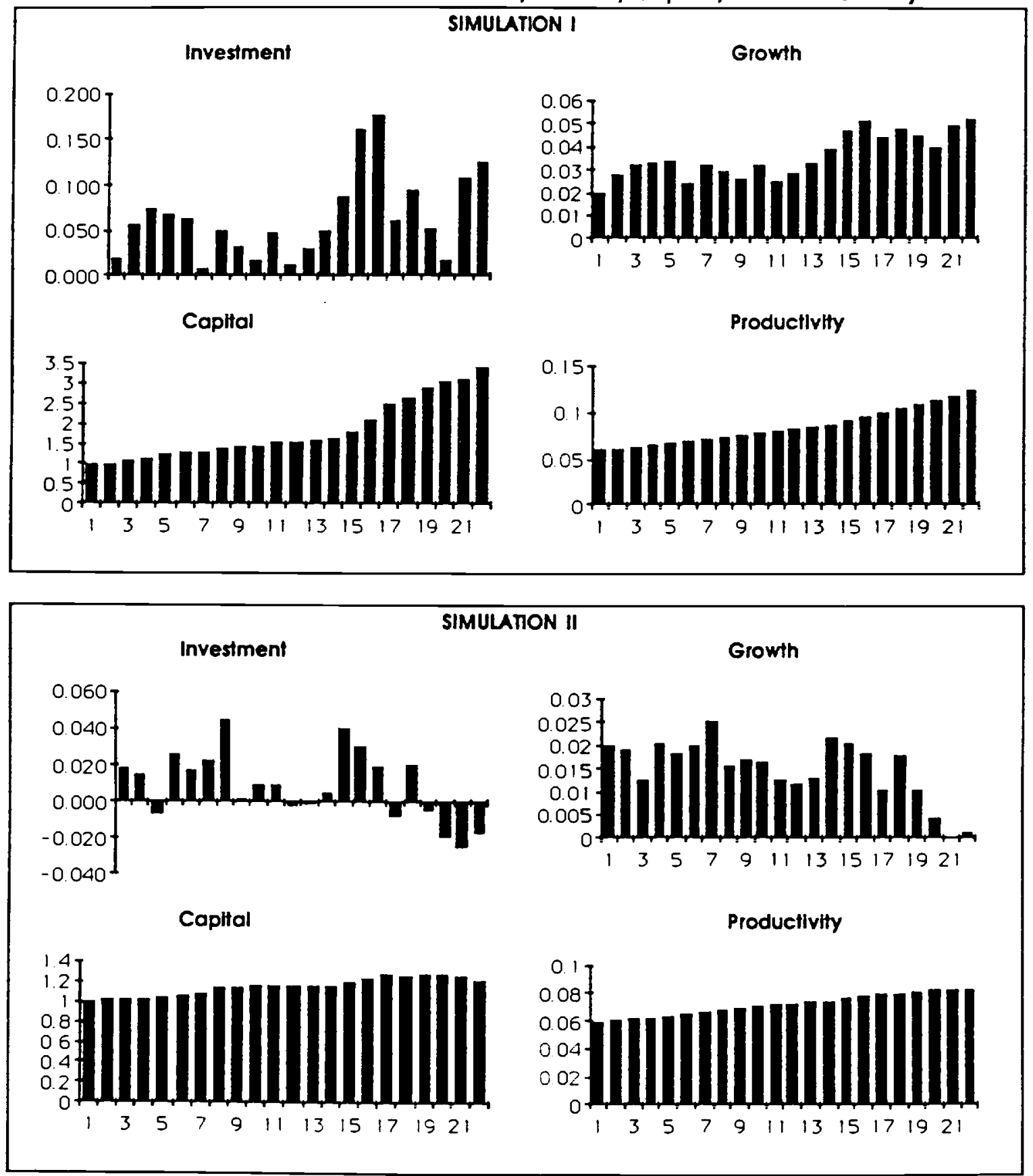

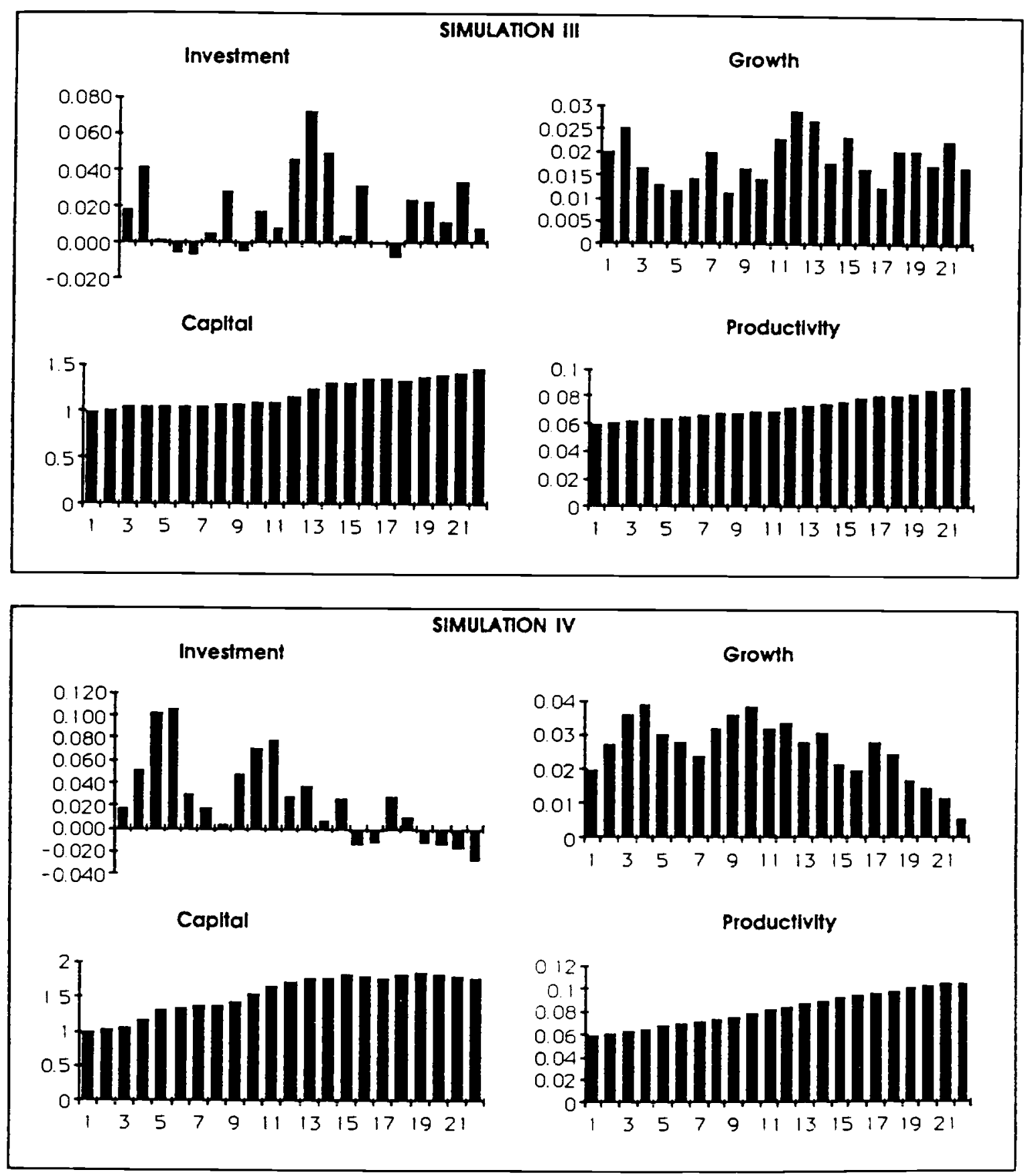
Flgure 7

SImulations: Optimal Investment Given Nows About Shifting Long-Run Growth
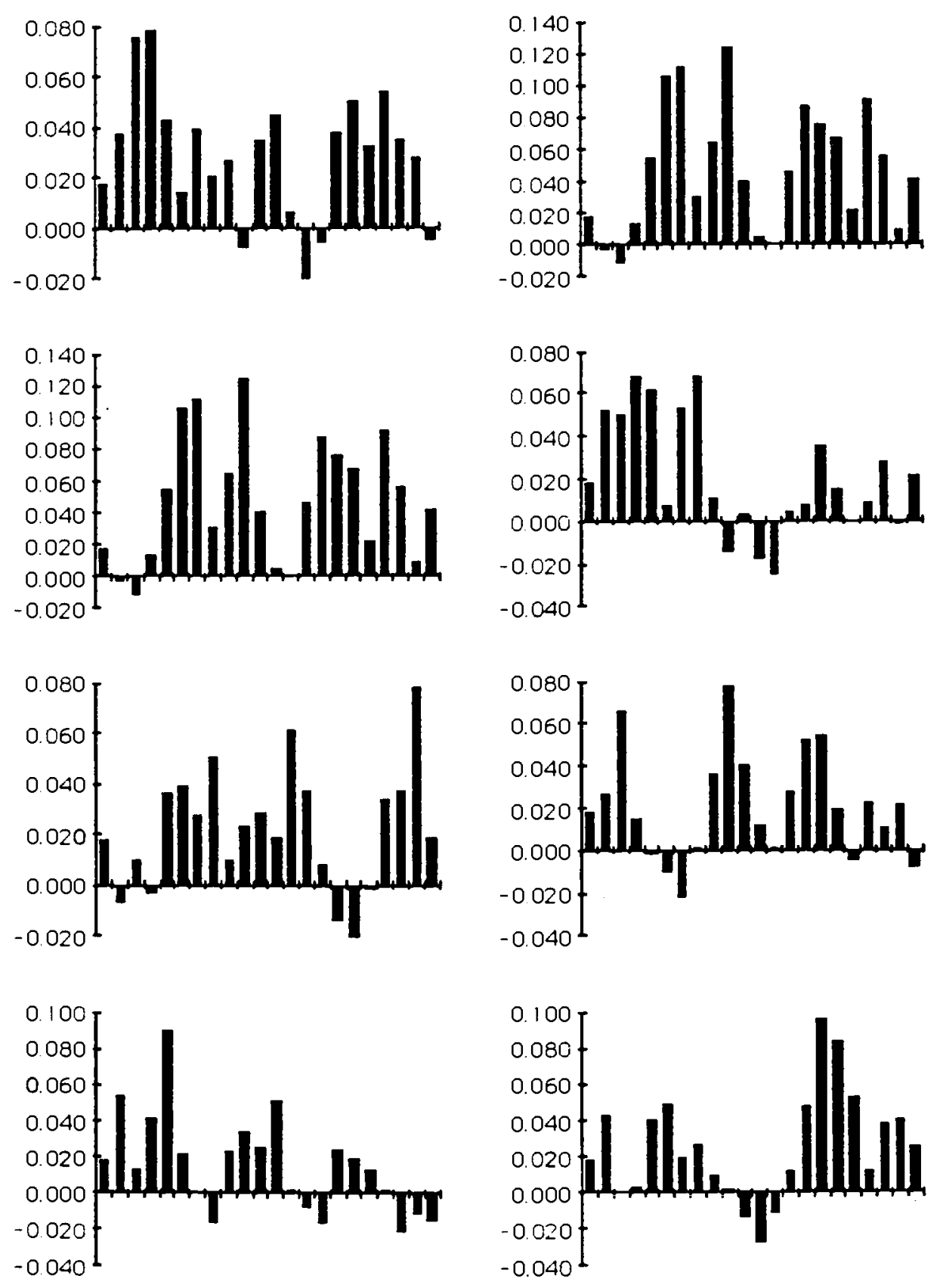

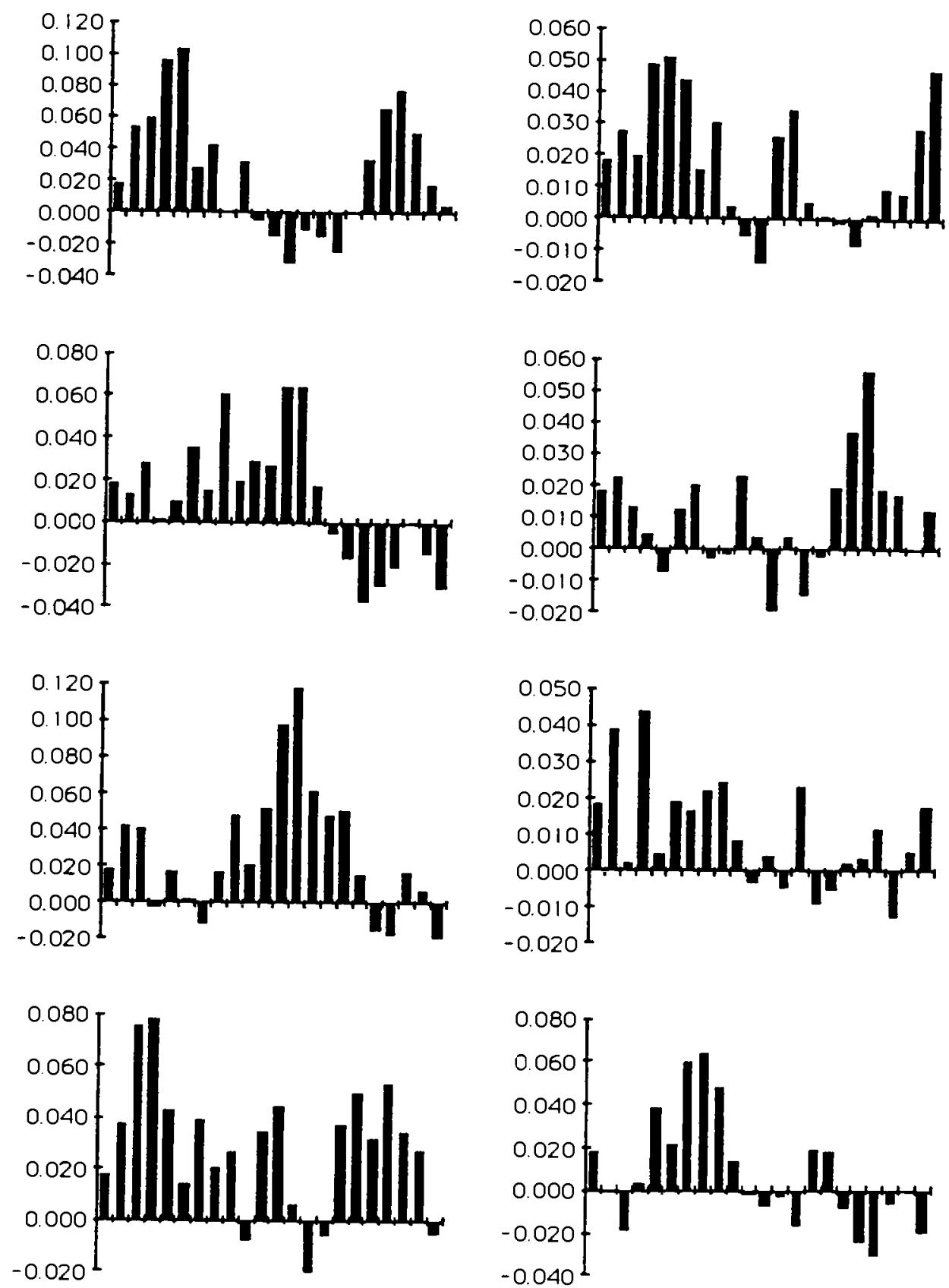
paths of investment, of the growth rate of the productivity parameter $\alpha$, of the capital stock $\mathrm{K}$, and of the level of the productivity parameter $\alpha$. Figure 7 presents the time paths of investment from sixteen simulation runs. ${ }^{12}$

The model does illustrate how investment booms and slumps can arise out of the optimal dynamic response of a growing economy to news about the future-and the model does not require the ad hoc assumption of technological regress, but merely the much more reasonable assumption that the path of future productivity growth is uncertain. The simulation runs thus reveal an important lesson. The underlying "fundamental" in the simulations-the level of the technology parameter $\alpha$-follows a very smooth path over time. There are substantial costs of adjusting $\mathrm{K}$ : too high a rate of investment or disinvestment in the short run quickly becomes very expensive, and there are strong incentives to smooth out the path of investment over time. Yet even though the underlying fundamental is smooth and there are substantial incentives to smooth investment, the actual time paths of investment plotted in the simulation runs are sharp, jagged. and variable. These jagged paths are optimal in the assumed stochastic environment. Smoothness of the path of fundamentals to the eye and incentives to smooth the control variable do not necessarily imply that the optimal path for the control variable will itself be smooth to the eye. ${ }^{13}$

The simple model constructed here is unsatisfactory for several reasons. First, this is by no means a full model of the business cycle. It accounts for why desired investment spending might fluctuate a significant amount given a constant shadow cost of using resources to produce investment goods, but it provides no account of why resources appear to lie idle after their release from the investment-goods sector, or for why-given that they will lie idle-their market cost does not fall enough to make continued investment profitable. Second, the model fails to

\footnotetext{
12 Parameter values in the simulation runs are illustrative only: the discount rate $r$ is set at $7.5 \%$, the responsiveness $\delta$ of investment to shifts in $q$ is set at 0.2 , the initial rate of growth $\gamma_{0}$ of productivity is set at $2 \%$ per period, and each period $\gamma$ is subject to a permanent shock $\&$ with standard deviation $0.6 \%$.

${ }^{13}$ In a sense, this is the same point as that made by Kleidon (1986). Investment responds not to movements in $\alpha$ but to movements in the expected discounted value of all future $\alpha$ 's. Even though $\alpha$ shifts only a small amount from period to period, the unstable nature of future productivity growth means that the expected discounted value of all future $\alpha$ 's shifts substantially.
} 
deal sufficiently with the irreversibility of investment-capital can be broken down into consumption goods using the same technology with which it is built up. Schumpeter and others placed great stress on how recessions occured when the economy had not only "too much" but also the "wrong kinds" of capital goods. Third, the model does not deal with the interaction of the monetary sector with the real economy -an interaction that many liquidationists considered key in preventing the early recognition of overbuilding. ${ }^{14}$

\section{Impllcations}

\section{Economic Policy in a "Liquidationist" Framework}

From the perspective of an economist who believes the model of business cycles laid out in section III, the policy recommendations of Hayek, Mellon, Robbins, Schumpeter and others- to let the private sector deal with the Great Depression, and to at all costs avoid any "inflationary" policy that might prop up real aggregate demand-appear sound and reasonable.

Suppose that the government takes active policy steps to prop up aggregate demand and keep investment high once the depression begins by buying bonds, supporting their price, and so reducing the real interest rate below its long-run equilibrium value so that stock prices and investment will remain high. What are the consequences of high investment? Since the productivity parameter $\alpha$ is no longer growing rapidly, high investment implies that $\mathrm{K} / \alpha$ steadily increases. As long as the government maintains its stimulative policy, the economy moves to the right along the (old) $\mathrm{K} / \alpha=$ constant locus, from point $A$ toward point $D$ in figure 8 .

Eventually the policy of easy money must break down. The govemment cannot hold the real interest rate below its equilibrium value of $r$ indefinitely, and cannot support real stock prices at their boom levels indefinitely. Should it try to do so, it will have to print larger and larger

\footnotetext{
14 Another defect is that the model has no space for agents who do not optimally process information. "Liquidationists" had no methodological predisposition against the belief that some investors make "mistakes" not only ex post but also ex anie, and that a depression could become necessary not only because of bad fundamental news but also because of a central bank failure to check irrational speculative excess. This branch of the "liquidationist" perspective is suppressed here.
} 
quantities of money and a hyperinflation will result. So eventually - say when the economy is at point $D$ - the easy money policy will (suddenly and unexpectedly) break down, and the real interest rate will revert to its equilibrium value of $r$.

At that moment the stock market crashes, and the economy jumps instantaneously to point $E$ in figure 8 . When the government began its easy money policy, the economy had a capital overhang - caused by bad news about future productivity growth-equal to the difference in the horizontal coordinates of points B and C. If the government had let the private sector handle the Depression, a period of liquidation would have ensued during which the economy would have progressed from $B$ to $C$.

After the easy money policy has broken down, the capital overhang is much greater-equal to the difference in the horizontal coordinates of points $\mathrm{E}$ and $\mathrm{C}$. The period of "liquidation" and depression that will ensue following the end of the easy money policy will be much more prolonged, and much more painful, than the original recession would have been had the government not tried to fight it.

\section{Figure 8}

\section{The Destructive Effects of Stimulative Policles}

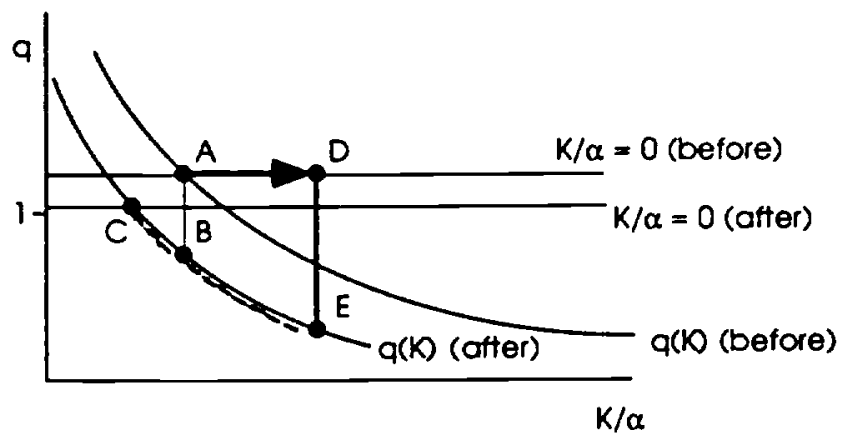

Govemment policy has interfered with relative prices, and has led to the piling up of more and more capital at just that moment when the shadow value of capital was very low and the market system was broadcasting the signal that the economy had overinvested and needed a 
period of quiescence to work off its capital overhang. Instead, the government blocked this message with its easy money policy, and so created a capital overhang of much larger proportions. Originally, just that part of the economy's capital between points $B$ and $C$ was not yielding sufficient quasi-rents to cover its cost of production; after the easy money policy, all of the economy's capital between points $\mathrm{E}$ and $\mathrm{C}$ is not worth what it cost to put in place.

This or a less formalized doctrine akin to this-was the argument that lay behind the aversion to stimulative policies that political figures like Mellon and academic figures like Schumpeter felt during the Great Depression. The argument is logically consistent if the premise about the cause of depressions is accepted. But why were so many willing to accept the premise? Certainly Keynes (1931; pp. 347-8) devoted a substantial part of his Chicago lecture on the Depression to arguing that the boom of 1925-29 had not produced an economy with an unsustainable or an unbalanced capital structure:

While some part of the investment...was doubtless ill judged and unfruitful, there can....be no doubt that the world was enormously enriched by the constructions of ...1925 to 1929; its wealth increased in these five years by as much as in any other ten or twenty years of its history.... [O]n the whole, I see little sign of any serious want of balance such as is alleged by some authorities. The rates of growth [of different sectors]...seem to me...to have been in as good a balance as one could have expected....A few more quinquennia of equal activity might, indeed, have brought us near to the economic Eldorado where all our reasonable economic needs would be satisfied.

\section{Late-Nineteenth Century Railroad Cycles}

One possible answer is that the "liquidationist" point of view is not completely without merit. In countries that are undergoing rapid industrial revolutions and seeing rapid increases in their capital/output ratios, swings in investment driven by news about future growth rates will be proportionately more important than in countries that have already undergone their industrial revolutions and have attained relatively stable capital/output ratios. 


\section{Flgure 9}

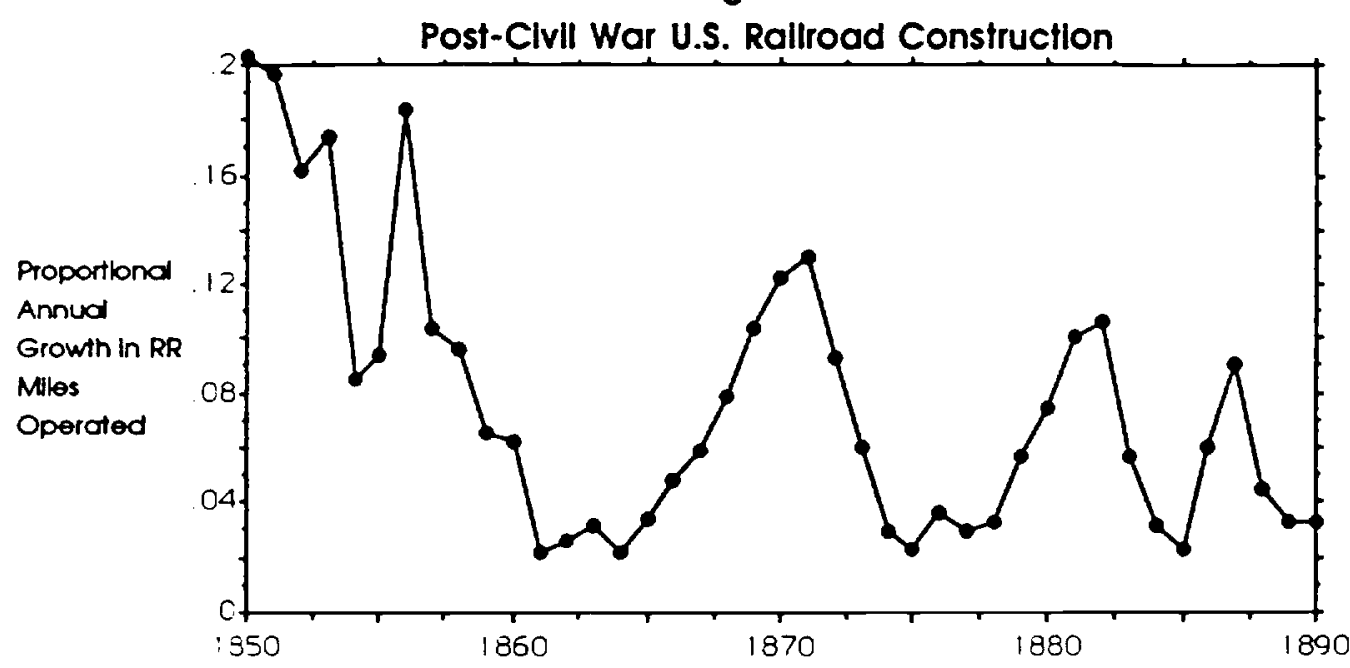

In the United States, the half century before World War II saw the non-agricultural capital/output ratio nearly double (Abramovitz and David, 1973). A "liquidationist" perspective might well have been a relatively good model for such pre-World War I business cycles in the United States (or in other rapidly industrializing countries like Germany). If the causes of business cycles can be characterized as "Schumpeterian," "Keynesian," or "monetarist," then an economy like the pre-WWI U.S. would presumably see "Schumpeterian" causes at their relative maximum of importance.

For example, in 1870 and 1871, U.S. railroad construction reached its first post-Civil War peak. The number of miles of operated railroad in the U.S., then around 50,000, grew at about twelve percent per year. The construction of these 6,000 miles of railroad track each year (up from approximately 600 miles/year during the Civil War) required approximately one-tenth of America's non-farm paid labor force, and perhaps half of the production of America's capital goods industries. Four years later, in 1875 , U.S. railroad construction had collapsed. In 1875 , operated railroad mileage grew at only three percent-less than 2,000 miles of railroad were built. Railroad construction involved less than three percent of America's non-farm paid labor force, and consumed perhaps fifteen percent of the potential production of America's capital goods industries. 
As figure 9 shows, two more substantial but irregular waves of railroad construction, one peaking in 1881-2 and a second smaller wave peaking in 1887, passed through the American economy before 1890 . Each required a substantial expansion of capacity in the railroad construction sector's supplier industries-iron and steel for rails, timber for ties, mechanical equipment for locomotives and cars, furniture to equip the Pullman Co. cars to carry passengers on the new lines, and so forth-and a redirection of capacity from other industries and from idle status to the production of railroad lines. Each wave of construction also required the redirection of perhaps one million workers to railroad construction, and as the wave passed their reallocation into other sectors or into relative idleness. These swings in railroad construction, and the swings in total product associated with them, are what contemporaries first described by the term "business cycles."

Figure 10

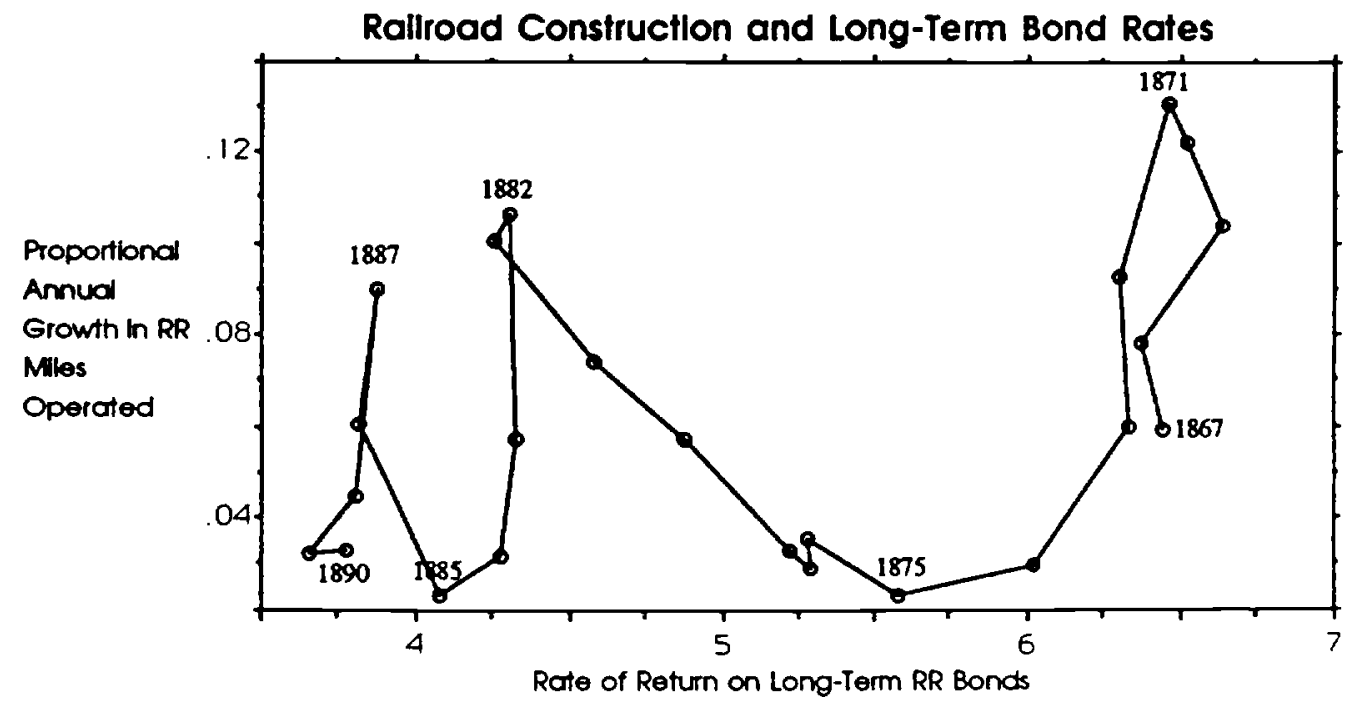

It is hard to interpret such late nineteenth-century railroad cycles as caused by the forces to which business cycles are often attributed today. The small government did not serve as a source of more than trivial fiscal shocks. There was no central bank to mistakenly squeeze off economic activity by letting the money supply grow too slowly. Indeed, the typical correlation 
goes the wrong way: the post-1871 fall in railroad construction is associated not with rising but with steeply falling interest rates, as figure 10 shows. It is difficult to attribute the railroad cycles to disturbances in financial markets: the financing of railroads was the predominant business of financial markets, and financial crises tended to result from downtums in railroad construction, not to cause such downturns.

Nor can late nineteenth century railroad cycles be attributed to sudden disturbances on the supply side. There do not appear to be any candidate negative technology, cost, or supply shocks to account for the collapse of U.S. railroad investment in the 1870's and 1880's; American workers and firms did not forget how to build railroads efficiently, the market for crop exports did not collapse, and wages did not suddenly rise by unusual amounts.

By default, therefore, a "Schumpeterian" view of U.S. late nineteenth century railroad cycles appears as plausible as any. There was tremendous uncertainty about the long run growth of the American economy, especially where the settlement of the West is concerned. Railroads are investments that are very sensitive to the growth of the region that they serve. Entrepreneurs did risk their fortunes and futures on their assessment of the quasi-rents to be eamed from the traffic on a particular railroad line. Sometimes they guessed wrong: the bond house of Jay Cooke and Co. failed because it had advanced far more money for the construction of the Northern Pacific than it could recoup by selling the Northern Pacific's bonds. The failure of Jay Cooke and Co. ushered in the panic of 1873 and the subsequent depression, which did not lift until five years had passed and railroad construction resumed.

At the very least, the railroad booms and busts of the late nineteenth century are not inconsistent with a "liquidationist" perspective. When long run rates of growth are unstable, investment for the future ought to be jagged, and ought to see periods of rapid expansion coupled with periods of quiescence and disinvestment. This was Schumpeter's insight. ${ }^{15}$

\footnotetext{
${ }^{15}$ Large jagged swings in the rate of investment driven by news about expected future growth may have wider relevance. Barsky and De Long $(1989,1990)$ argued that an overwhelming proportion of decade-to-decade swings in the U.S. stock market in the twentieth century could be accounied for as consequences of changes in investors' expectations of the long run future dividend growth rate, tied to shifts in productivity and GNP growth rates as well. Blanchard, Rhee, and Summers (1990) find a strong relationship between the stock market and investment
} 
In this context, it does not seem surprising that "liquidationist" theories became popular around and after the turn of the twentieth century. They promised to make sense of relatively recent historical experience. When the Great Depression came, theorists like Robbins and Schumpeter tried to make sense of the Great Depression in the same framework. With hindsight we can see that the Great Depression was an order of magnitude larger than previous depressions, that the Great Depression was not a period of accelerated structural change, and that as a result it is difficult to sustain an interpretation that sees the Great Depression as a necessary period of economic housecleaning. Schumpeter and his school were, it may be, working within a macroeconomic framework that had once been reasonable, but had become inappropriate and that proved unhelpful in understanding and guiding policy during the Great Depression.

\section{Real Business Cycles}

Academic economics in the past decade has seen the growth of "real business cycle" theories in the aftermath of the decline of the "monetary misperceptions" school of business cycle analysis (Lucas, 1986). It is somewhat puzzling that such theories have rested their specifications of the production function on the observed behavior of the aggregate Solow residual. This has given a prominent place in "real business cycle" theory to inward shifts in the production function-total factor productivity regression-as the mechanism behind depressions.

Such a theory is, from some perspectives, profoundly unhelpful. The phenomena under study are immediate consequences of the assumption that technology regresses, and the assumption closes off further investigation of the empirical microfoundations of the theory. This research program has seen relatively few attempts to understand how technologies of production, market structures, and stochastic shocks might interact to produce endogenous declines in measured total factor productivity. Some attempts as have been made to construct credible

over the twentieth century. To the extent that the stock market and investment are responding to the same factors and that large stock market swings are driven by shifting expectations of future growth, there appears to be a possibility that "Schumpeterian" investment dynamics have played a role in shaping the strength of business cycles, even if they have not determined their timing. 
empirical microfoundations (Lilien, 1982; Brainerd and Cutler, 1990) for such theories. And some attempts have been made to construct theoretical building blocks (Murphy, Shleifer, and Vishny, 1989) for market-clearing business cycle models. These attempts have not been well received by real business cycle theorists, who appear to argue that the declines in measured total factor productivity during downtums are the only microfoundations needed (Prescott, 1989).

Such a reliance on an ad hoc specification of technology is strange given the availability of the Hayek-Robbins-Schumpeter frameworks, which do not rely on large-scale total factor productivity regression to account for depressions, and which have been available for revivification. Since the specification of technology has been the principal stumbling block to progress in real business cycle theory, it seems likely a framework like Schumpeter's-which promises to generate "optimal" and "real" business cycles without requiring large-scale technological regression-could support a much more productive and progressive research program than that of present real business cycle theory.

\section{Conclusion}

This paper has two principal themes and one subsidiary theme. The principal themes are closely interlinked and deal, respectively, with the history of economic thought and with economic history. They are, first, that getting the history of economic thought right requires a sympathetic understanding of what the "liquidationist" perspective was and, second, that getting the history of economic policy during the Great Depression right requires an understanding of the strong hold over men's minds exercised by the "liquidationist" perspective. The subsidiary theme is that, when considered as "real business cycle" theories, Schumpeter (1934) appears much more attractive than Prescott (1984).

The Great Depression is one of the principal axes on which the history of the twentieth century turns. One of the most astonishing features of the Great Depression, from our point of view, is the extreme unwillingness of governments to take active steps to stimulate their economies during the slide of 1929-33. Those deciding on economic policy during the Great 
Depression acted like "madmen in authority" (Keynes, 1936). And they were ruled by the theories of academic scribblers who built up and advanced the "liquidationist" perspective.

Advocates of the "liquidationist" perspective argued that the Great Depression had come about because the boom of the 1920's had led to a capital overhang, and that investment could not proceed until the pace of productivity growth and of depreciation had eliminated this excess of produced means of production. By and large, the policy recommendations of the "liquidationists" were followed for much of the Depression.

A large proportion of the capital stock was indeed liquidated. According to Blanchard, Rhee, and Summers (1990), by 1936 all of net capital accumulation over 1924-29 had been erased. Yet the years between 1936 and World War I did not see a restoration of normal levels of activity and unemployment. This is as decisive an experiment as could be wished for: whatever caused the Great Depression and no matter how applicable "liquidationist" theory may be to other episodes, the Great Depression was not caused by an overhang of unproductive capital for the Depression outlasted any plausible such overhang.

It was, therefore, bad advice that academic economists like Robbins and Schumpeter gave central banks and treasuries during the Great Depression. It is disturbing that so many very smart economists could give such irrelevant and unproductive policy advice in such a serious siruation. It is also disturbing that the advice they gave sounds not unreasonable given their theoretical and empirical knowledge of market economies. The market economy's allocation of resources between consumption and investment does involve the market's solving a dynamic maximization problem in a stochastic environment. The arrival of news about future productivities and opportunities does imply that there will be times at which new information reveals that recent investment projects will not repay their social costs. In such situations, the correct policy is indeed to help the process of structural readjustment and sectoral reallocation along, and not to delay reallocation by pumping up demand to freeze production in its old pattem.

The advocates of the "liquidationist" point of view during the Great Depression were mistaken, but they were not crazy. Their failure to recognize the severity and scope of the Great Depression is a severe indictment: Schumpeter (1934) gives no sign of recognizing that 1929-33 
was any larger than 1907-08, yet the Great Depression as five times as deep and five times as long-twenty-five times larger in total magnitude. ${ }^{16}$ In standard histories (Chandler, 1973) or accounts of the Keynesian Revolution (Galbraith, 1965), the policy recommendations given by the liquidationists appear to be nothing but incoherent barbarisms that were, for some inexplicable reason, believed. Such an interpretation gets the history of economic thought wrong. It also creates a climate of undue smugness among the present generation of economists. It is one thing to compare past barbarism to present civilization. It is another to reflect that Robbins and Schumpeter were as smart and as hard working as anyone in more recent generations of economists-and they were also as sure that they were right.

16 However, he lacked the base of quantitative data on the course of the business cycle that we take for granted 


\section{References}

Moses Abramovitz and Paul David (1973), "Reinterpreting American Economic Growth: Parables and Realities," American Economic Review Papers and Proceedings 63 (May), pp. 428-39.

Robert Barsky and J. Bradford De Long (1989), “Why Have Stock Prices Fluctuated?" (Cambridge, MA: Harvard University xerox).

Robert Barsky and J. Bradford De Long (1990), "Bull and Bear Markets in the Twentieth Century," Journal of Economic History 50 (June), pp. 265-81.

Olivier Blanchard and Stanley Fischer (1988), Macroeconomic Theory (Cambridge, MA: M.I.T. Press).

S. Lael Brainard and David Cutler (1990), "Sectoral Shifts and Cyclical Unemployment Reconsidered" (Cambridge, MA: Harvard University xerox).

Douglass Brown et al. (1934), Economics of the Recovery Program (New York: McGraw-Hill).

E. Cary Brown (1956), "Fiscal Policy in the Thirties: A Reappraisal," American Economic Review 46 (December), pp. 857-79.

Karl Brunner and Allan Meltzer (1974) "Friedman's Monetary Theory," in Robert J. Gordon, ed., Milton Friedman's Moneiary Framework (Chicago, Il.: University of Chicago Press, 1974).

Lester Chandler (1970), America's Greatest Depression (New York: Harper and Row).

J. Ronnie Davis (1971), The New Economics and the Old Economists (Ames, IO: University of Iowa Press).

Barry Eichengreen (1991), Golden Fetters: The Gold Standard and the Great Depression (forthcoming).

Milton Friedman and Anna J. Schwartz (1963), A Monetary History of the United States (Princeton, NJ: Princeton University Press).

Milton Friedman (1974), "Comments on the Critics," in Robert J. Gordon, ed., Milton Friedman's Monetary Framework (Chicago, Il.: University of Chicago Press, 1974). 
Milton Friedman (1984), "Monetary Policy for the 1980's," in John Moore, ed., To Promote Prosperity (Palo Alto, CA: Hoover Institution).

John Kenneth Galbraith (1965), "How Keynes Came to America," in John Kenneth Galbraith, Economics, Peace, and Laughter (Boston, Mass.: Houghton Mifflin, 1971).

Robert J. Gordon, ed. (1974), Milton Friedman's Monetary Framework (Chicago, Il.: University of Chicago Press).

Peter A. Hall, ed. (1989), The Political Power of Economic Ideas: Keynesianism Across Nations (Princeton, N.J.: Princeton University Press).

Seymour Harris (1934), "Higher Prices," in Douglass Brown et al., Economics of the Recovery Program (New York: McGraw-Hill, 1934).

Friedrich A. von Hayek (1935), Prices and Production (London: Routledge).

Friedrich A. von Hayek (1931), “The 'Paradox' of Saving," Economica 32 (May), pp. 125-69.

Herbert Hoover (1952), The Memoirs of Herben Hoover (New York: Macmillan and Co.).

Harry Johnson (1969), "The Keynesian Revolution and the Monetarist Counter-Revolution," in Harry Johnson and Elizabeth Johnson, In the Shadow of Keynes (Oxford: Basil Blackwell, 1978).

John Maynard Keynes (1931), “An Economic Analysis of Unemployment” (University of Chicago: 1931 Harris Foundation lectures); reprinted in John Maynard Keynes, The General Theory and Afier: Pant I, Preparation, vol. XIII, pt. 1 of The Collected Writings of John Maynard Keynes, Donald Moggridge, ed., (Cambridge, U.K.: Cambridge University Press, 1972).

John Maynard Keynes (1936), The General Theory of Employment, Interest and Money (Cambridge, UK: Cambridge University Press).

Charles P. Kindleberger (1978), Manias, Panics, and Crashes (New York: Basic Books).

Allen Kleidon (1986), "Variance Bounds Tests and Stock Price Valuation Models," Journal of Political Economy 94, pp. 953-1001.

David Lilien (1982), “Sectoral Shifts and Unemployment," Journal of Political Economy

Robert E. Lucas (1981), Studies in Business Cycle Theory (Cambridge, MA: M.LT. Press). 
Robert E. Lucas (1986), Models of Business Cycles (New York, NY:Basil Blackwell).

Kevin Murphy, Andrei Shleifer, and Robert Vishny (1989), “Building Blocks of Market Clearing Business Cycles," NBER Macroeconomics Annual

Donald Patinkin (1982), Anticipations of the General Theory, and Other Essays on Keynes (Chicago, In: University of Chicago Press).

Edward Prescott (1989), "Comment on Murphy, Shleifer, and Vishny," NBER Macroeconomics Annual.

Edward Prescott (1984), "Theory Ahead of Business Cycle Measurement," Federal Reserve Bank of Minneapolis Quarterly Review

Walter S. Salant (1989), "The Spread of Keynesian Doctrines and Practices in the United States," in Peter A. Hall, ed., The Political Power of Economic Ideas: Keynesianism Across Nations (Princeton, N.J.: Princeton University Press, 1989).

Paul Samuelson (1988), "The Role of Alvin Hansen in the Keynesian Revolution" (Cambridge, MA: M.I.T. xerox).

Joseph Schumpeter (1934), “Depressions," in Douglass Brown et al., Economics of the Recovery Program (New York: McGraw-Hill, 1934).

Peter Temin (1990), Lessons from the Great Depression (Cambridge, MA: M.I.T. Press).

Peter Temin (1974), Did Monetary Forces Cause the Great Depression? (New York: W.W. Norton).

William Wiseley (1977), A Tool of Power: The Political History of Money (New York: John Wiley). 